\title{
TEKNOLOGI PENGOLAHAN TEH HERBAL DARI TANAMAN GAHARU DI KELURAHAN LAMBUNG BUKIK KOTA PADANG
}

\author{
Benni Satria $^{\left.{ }^{*}\right)}$, Nilla Kristina ${ }^{1}$, Afrima Sari ${ }^{1,}$ Indra Dwipa ${ }^{1}$, Armansyah ${ }^{1}$, Syahyana Raesi $^{2}$ \\ Ferry Lismanto Syaiful ${ }^{3}$ dan Trizelia ${ }^{1}$ \\ ${ }^{1)}$ Departemen Agroteknologi Fakultas Pertanian Universitas Andalas \\ 2) Department Agribisnis Fakultas Pertanian Universitas Andalas \\ 3) Fakultas Peternakan Universitas Andalas \\ *) Email: bennisatria@agr.unand.ac.id
}

\begin{abstract}
ABSTRAK
Masyarakat Kelurahan Lambung Bukik Kecamatan Pauh Kota Padang mayoritas bermata pencaharian bertani tanaman hortikultura, palawija, tanaman hutan (Sungkai dan gaharu) dan beternak sapi dan ayam. Kelompok Tani Sungkai Permai memiliki pohon gaharu yang telah berumur 2-5 tahun yang mana bibitnya diperoleh melalui kegiatan Elok Nagari CSR PT Semen Padang. Saat ini pohon gaharu tersebut sudah dapat berpotensi baik melalui inokulasi pathogen jamur pada pohon gaharu guna membentuk gubal gaharu yang bernilai ekonomi, maupun pemanfaatan daun menjadi minuman kesehatan. Kegiatan ini bertujuan: 1). masyarakat mengetahui cara budidaya tanaman gaharu, dan mengetahui manfaat dari tanaman ini serta tahu cara mengolah bagian dari pohon gaharu seperti gubal dan daun menjadi bahan baku minuman teh, 2). memberikan keterampilan khusus bagi anggota kelompok tani sehingga diharapkan dapat dijadikan sebagai salah satu usaha mandiri; 3). memberdayakan masyarakat dalam memanfaatkan lahan kosong melalui pola tanam agroforestri tanaman gaharu dengan tanaman perkebunan, 4). sebagai bentuk kegiatan kemasyarakatan dari Universitas Andalas, khususnya Fakultas Pertanian. Kegiatan ini dilaksanakan di kelompok Tani Sungkai Permai Kelurahan Lambung Bukik Kota Padang. Kelompok tani Sungkai Permai telah memperoleh pengetahuan tentang budidaya tanaman gaharu serta pemanfaatan teh melalui metode partisipatif dan pelatihan berupa demonstrasi dan demplot melalui penanaman lebih kurang 150 batang bibit gaharu sebagai bahan baku teh melalui pola agroforestri. Kelompok tani Sungkai Permai telah memperoleh pengetahuan pemanfaatan bagian gaharu menjadi teh gaharu sebagai minuman dan obat kesehatan dari daun dan gubal gaharu. Bahan baku daun dan gubal gaharu yang berasal dari pohon gaharu sekitar lahan petani di kelurahan Limau Manis atau daerah lain dapat dikelola oleh kelompok Tani Sungkai Permai dapat menjadi peluang usaha produktif sebagai teh dan obat dalam bentuk minuman kesehatan untuk meningkatkan perekonomian masyarakat.
\end{abstract}

Kata Kunci: gaharu, teh, lahan kosong, agroforestri

\section{Technology of Processing Herbal Tea from Gaharu Plants in Lambung Bukik Village Padang City}

\begin{abstract}
The majority of Lambung Bukik Village people, Pauh Subdistrict, Padang City, make a living from farming horticultural crops, secondary crops, forest plants (Sungkai and gaharu) and raising cattle and chickens. The Sungkai Permai Farmer Group has a 2-5-year-old gaharu tree, the seeds obtained through the Elok Nagari CSR activities of PT Semen Padang. Currently, the agarwood tree has good potential through the inoculation of fungal pathogens on the agarwood tree to form economically valuable sapwood and the use of its leaves as a health drink. This activity aims to: 1). the community knows how to cultivate agarwood plants, know its benefits, and know-how to process parts of the agarwood tree, such as sapwood and leaves, into raw materials for tea drinks, 2). provide special skills
\end{abstract}


for farmer groups members so that they are expected to be used as independent businesses; 3). They empower the community in utilizing empty land through the cropping pattern of aloes agroforestry with plantation crops, 4). as a form of community activity from Andalas University, especially the Faculty of Agriculture. This activity was carried out in the Sungkai Permai Farmer Group, Lambung Bukik Village, Padang City. The Sungkai Permai farmer group has acquired knowledge about gaharu cultivation and tea use through participatory methods and training in the form of demonstrations and demonstration plots by planting approximately 150 gaharu seeds as raw material for tea through an agroforestry pattern. The Sungkai Permai farmer group has acquired knowledge of using the part of gaharu to become aloe tea as a drink and health medicine from the leaves and sap of aloes. The Sungkai Permai farmer group can manage raw materials for gaharu leaves and sap derived from gaharu trees around farmers' land in Limau Manis sub-district, or other areas. They can be a productive business opportunity as tea and medicine in health drinks to improve the community's economy.

Keywords: agroforestry, improve, gaharu's tea, sapwood, service-learning

\section{PENDAHULUAN}

Kondisi geografis kelurahan ini berupa daerah yang relatif rendah dengan ketinggian lebih kurang 100-200 m di atas permukaan laut, beriklim sedang, dengan suhu udara 25-34 0C. Keadaan tanah pada umumnya subur.Penggunaan tanah selain untuk pemukiman pada umumnya adalah untuk lahan pertanian, perikanan dan lainnya. Penduduk di Kelurahan Lambung Bukik sebagian bermata pencarian bertani sawah dan ladang, beternak dan sebagian lagi pegawai negeri, buruh dan wira swasta. Salah satu kelompok tani yang bergerak di bidang pertanian adalah kelompok tani Sungkai Permai.

Kelompok tani UPPO Sungkai Permai berada di Kelurahan Lambung Bukik kecamatan Pauh kota Padang dan jarak dari Kampus Unand Limau Manis sekitar $2 \mathrm{~km}$. Kelompok Tani Sugkai Permai ini beranggota 40 orang, dan berpendidikan rata-rata SMA. Kelompok tani Tunas Sungkai Permai, sebagian anggota kelompoknya telah mengenal tanaman gaharu baik melihat langsung di lapangan di sekitar Kampus Unand Limau Manis, membaca buku dan informasi dari majalah dan buku, serta ada pula yang telah menanam bibitnya sekitar 2 tahun yang lalu (Hasil wawancara pribadi, 2016).

Kelurahan Lambung Bukik memiliki beberapa kelompok tani yang bergerak di bidang pertanian terutama tanaman perkebunan dan hutan seperti pemberdayaan ladang kelompok tani Sungkai Permai yang tidak ditanami selama ini melalui agroforestri tanaman gaharu diantara tanaman perkebunan dan pengolahan teh herbal dari tanaman gaharu. Kegiatan ini merupakan kegiatan bersama antara Fakultas Pertanian (Dies Natalis), LPPM Universitas Andalas (Dies Natalis), DPP IKA Unand dan Pemko Kota Padang (Ulang Tahun Kota Padang). Proses perencanaan kelompok muncul berbagai macam Rencana Tindak Lanjut (RTL), salah satu diantaranya bagaimana memberdayakan lahan yang tidak dikelola dengan menanam tanaman gaharu diantara tanaman perkebunan seperti tanaman kakao. Hasil survei yang dilakukan Satria dan Aisyah (2011) 35 \% petani di Kelurahan ini khususnya di kelompok tani Sungkai Permai telah mengetahui sedikit banyaknya tentang tanaman gaharu melalui pelatihan yang telah didapatkan pada waktu mewakili kelompok tani di kelurahan Limau Manis. 
Tanaman gaharu selama ini yang di produksi hanya gubal gaharu . Produksi gubak gaharu selama ini hanya mengandalkan produksi alami yang ada di hutanhutan/ladang, kalau pun ada masih sangat tradisional, tanpa sentuhan teknologi baik dari aspek budidaya tanaman dan aspek pembentukan gubalnya serta aspek pemanfaatan gubal dan daun gaharu sebagai bahan teh untuk kesehatan (Raesi dkk, 2008; Satria dkk, 2008; dan Satria dkk, 2009). Penebangan tegakkan pohon hanya berdasarkan perkiraan yang sudah menghasilkan gubal secara alami. Sering kali terjadi penebangan yang sia-sia, akibat kurang keterampilan para pemburu/petani gaharu dalam mengenali pohon yang sudah membentuk gubal (Faisal, 2005; Poniran dan Satria et al, 2008).

Untuk pemanenan daun dan pucuk dilakukan mulai pada pohon sudah berumur di atas 1 tahun sampai 4 tahun, pemanenan daun dan pucuk dilakukan 1/3 dari jumlah daun/pucuk yang ada dalam satu pohon, dengan interval pemanenan 4 bulan sekali (Satria, 2009); Satria, 2012; dan Satria 2014. Dengan pemanenan daun selama 3 tahun maka secara tidak langsung juga bisa membuat tanaman gaharu menjadi stress yang dapat mengeluarkan senyawa resin yang akhirnya menambah produksi gubal sebelum pohon tersebut diperlakukan.

Kelompok mitra dari kegiatan ini adalah Kelompok Sungkai Permai memiliki ladang /kebun seluas $50 \mathrm{Ha}$, dengan kondisi tinggal dan tidak dikelola dengan baik. Selama ini petani banyak yang tidak mengetahui pemanfaatan tanaman gaharu, da nada diantara petani hanya memburu gubal gaharu yang terbentuk secara alami dan memiliki keterbatasan produksi dan gubal yang diperoleh dijual ke penampung, tetapi petani tidak mengetahui nilai ekonomi dari bagian lain dari tanaman gaharu, seperti daun, pucuk, dan serbuk gubal gaharu yang bermanfaat untuk kesehatan, hal ini terjadi karena yang kurang sosialisasi dan pengetahuan masyarakat yang masih rendah.

Menurut Satria et al., (2005-sekarang) telah menganalisis kandungan daun dan gubal gaharu dimana terdapat 22 senyawa untuk bahan baku obat 20 penyakit dan saat ini daun dan gubal gaharu kelas rendah telah di ramu dan dijadikan bahan minuman teh yang berguna untuk kesehatan. Dari testimoni yang dilakukan terhadap 200 orang maka sudah banyak melaporkan khasiat dari teh tersebut seperti sakit diabetes setelah minum teh gaharu 2 kali sehari dalam waktu 2- 7 hari kadar gula darah turun dari 850 menjadi 150, sakit batu ginjal dalam 7 hari batu ginjalnya pecah; sakit tumor Miom atau kista di rahim dalam waktu 2 bulan, sel tumornya normal kembali, sakit asam urat dalam 3-5 hari normal kembali, darah tinggi dalam waktu 1-2 hari normal; insomonia dalam waktu 1-2 hari normal, menormalkan denyut jantung; menguatkan daya ingat, anti stress.

Mempelajari segala kondisi tersebut, dipandang perlu dilakukan sosialisasi tentang budidaya tanaman gaharu umumnya, pemanfaatan lahan tidur dan yang tidak dikelola secara maksimal, sehingga dapat dimaksimalkan melalui pemberdayaan masyarakat tani melalui agroforestri tanaman gaharu diantara tanaman perkebunan dan pengolahan teh herbal dari tanaman gaharu di kelompok Tani Sungkai Permai

Pemanfaatan daun tanaman gaharu sebagai teh kesehatan secara khusus serta proses pembuatan teh kesehatan dari daun tanaman gaharu. Kelompok didampingi untuk melakukan Fokus Group Diskusi (FGD). Anggota kelompok dilibatkan secara aktif untuk mengemukakan pendapatnya tentang budidaya gaharu, dan proses 
pembuatan teh dari daun tanaman gaharu. Kegiatan praktek akan dibagi menjadi dua bentuk yakni pelatihan teknik pembuatan teh dan penanaman secara simbolis bibit gaharu. Pelatihan ditujukan untuk menambah wawasan dari petani bagaimana cara pemetikan daun atau pucuk gaharu sebagai bahan teh kesehatan.

Adapun pendampingan lapangan ditujukan untuk melatih keterampilan mereka dalam teknik pemetikan daun dan pucuk, teknik produksi gubal gaharu serta pembuatan teh kesehatan. Petani diharapkan dapat meluangkan waktu untuk mengikuti kegiatan tersebut secara penuh sampai tuntas, menyediakan demplot untuk penanaman bibit di lapangan, dan ikut serta melakukan pengamatan.

Adapun tujuan kegiatan ini adalah sebagai berikut: 1).Masyarakat mengetahui cara budidaya tanaman gaharu, dan mengetahui manfaat dari tanaman gaharu serta tahu cara mengolah bagian dari pohon gaharu seperti gubal dan daun menjadi bahan baku minuman teH; 2). Memberikan keterampilan khusus bagi anggota kelompok tani sehingga diharapkan dapat dijadikan sebagai salah satu usaha mandiri dan 3). Memberdayakan masyarakat dalam memanfaatkan lahan kosong melalui pola tanam agroforestri tanaman gaharu dengan tanaman perkebunan

Melalui pelaksanaan kegiatan ini diharapkan: 1). Petani di kelompok ini memiliki pengetahuan dan keterampilan yang cukup untuk budidaya tanaman gaharu, teknik pemetikan pucuk dan daun serta pembuatan teh gaharu agar meningkatkan nilai ekonomis; 2). Petani mampu mengolah daun serta pucuk gaharu sebagai bahan teh untuk kesehatan dan 3). Adanya modul teknik pembuatan teh untuk kesehatan berbasis kearifan lokal, yang dibuat bersama kelompok dampingan. Modul ini diharapkan menjadi panduan bagi kelompok dampingan dalam melakukan kegiatan usaha tanaman gaharu dan masyarakat lain yang melakukan usaha budidaya gaharu yang tidak mendapatkan dampingan dari kegiatan ini.

\section{METODOLOGI}

Kegiatan ini telah dilaksanakan selama 5 bulan di kelompok Tani Sungkai Permai kelurahan Lambung Bukik Kecamatan Pauh Kota Padang dengan sasaran kegiatan adalah para anggota kelompok tani khususnya dan kelompok tani sekitarnya. Kelompok tani Sungkai Permai berjumlah 30 orang anggota. Tahapan pelaksanaan kegiatan ini adalah sebagai berikut: 1). survey Lokasi yaitu tahap penjajakan lokasi dan rencana kegiatan dengan mitra; 2). perencanaan dan persiapan; 3).tahap ini merupakan tahap penyiapan alat dan bahan yang akan digunakan dalam kegiatan, penyiapan modul pelatihan, dan pengaturan waktu pelaksanaan kegiatan penyuluhan dan pelatihan pemanfaatan daun dan gubal gaharu sebagai bahan baku teh minuman kesehatan dan 4). Evaluasi dan pelaporan.

Alat dan bahan pembuatan Teh Gaharu meliputi antara lain: pisau, baskom, timbangan, blender, tikar, wadah, packaging, stiker; dan bahan yang digunakan meliputi antara lain: pucuk gaharu $1,0 \mathrm{~kg}$, daun muda gaharu $3,0 \mathrm{~kg}$, daun agak tua 2,0 $\mathrm{kg}$, air mengalir, gubal gaharu kelas rendah $0,5 \mathrm{~kg}$.

Cara kerja: 1. Pucuk, daun muda dan daun agak tua diletakkan ke dalam baskom, lalu di rendam dan dicuci bersih di cuci bersih, selanjutnya ditiriskan, setelah 

e-ISSN: 2621-7198

itu diletakkan di atas tikar dan dijemur dalam ruang penjemuran pada suhu kamar selama 3-5 hari, dimana setiap hari daun di bolak balik. Apabila sudah kering angin, lalu bahan dimasukkan dalam oven pada suhu 70\% dan diukur kadar air sampai 10\%., 2. Pucuk, daun muda dan daun agak tua gaharu yang telah kering sempurna pada kadar air 10\% kemudian di blender atau di masukkan ke dalam mesin prosesing bahan baku menjadi teh gaharu(Gambar 1) dan hasilnya diletakkan dalam tupper ware, 3. Gubal gaharu kelas rendah dimasukkan dalam mesin pengolah sampai menjadi tepung, lalu dimasukkan dalam tupper ware dan 4 . Teh gaharu yang telah jadi dalam tupper ware dicampur dengan serbuk gaharu dengan perbandingan (4:1), lalu masukkan ke dalam plastic packaging dan diberi stiker di plastik tersebut.

\section{HASIL DAN PEMBAHASAN}

Pemberdayaan masyarakat tani di kelompok tani Sungkai Permai diawali dengan pembukaan kegiatan yang dibuka oleh bapak Walikota Padang yang didahului oleh sambutan ketua kelompok tani, ketua tim pengabdian, bapak Rektor Unand dan bapak Walikota Padang Kegiatan ini juga dikaitkan dalam rangka menyambut Lustrum Unand ke 12, Kongres IKA Unand ke-4 dan HUT kota Padang ke 227, yang dihadiri oleh 200 orang peserta yang terdiri dari: 50 orang kelompok tani, 25 orang mahasiswa, 50 orang pemuka masyarakat dan Pemerintahan Kota serta 75 orang dosen dan tenaga kependidikan Unand Ditinjau dari kegunaan dan pemanfaatan bagian tanaman gaharu sebelum dilakukan sosialisasi atau penyuluhan budidaya tanaman gaharu dan pemanfaatannya ternyata anggota kelompok tani banyak yang belum mengetahuinya, sehingga pada saat dilakukan penyuluhan hampir 90\% dari anggota kelompok tani sebagai peserta yang hadir bertanya secara detail (Gambar 1).
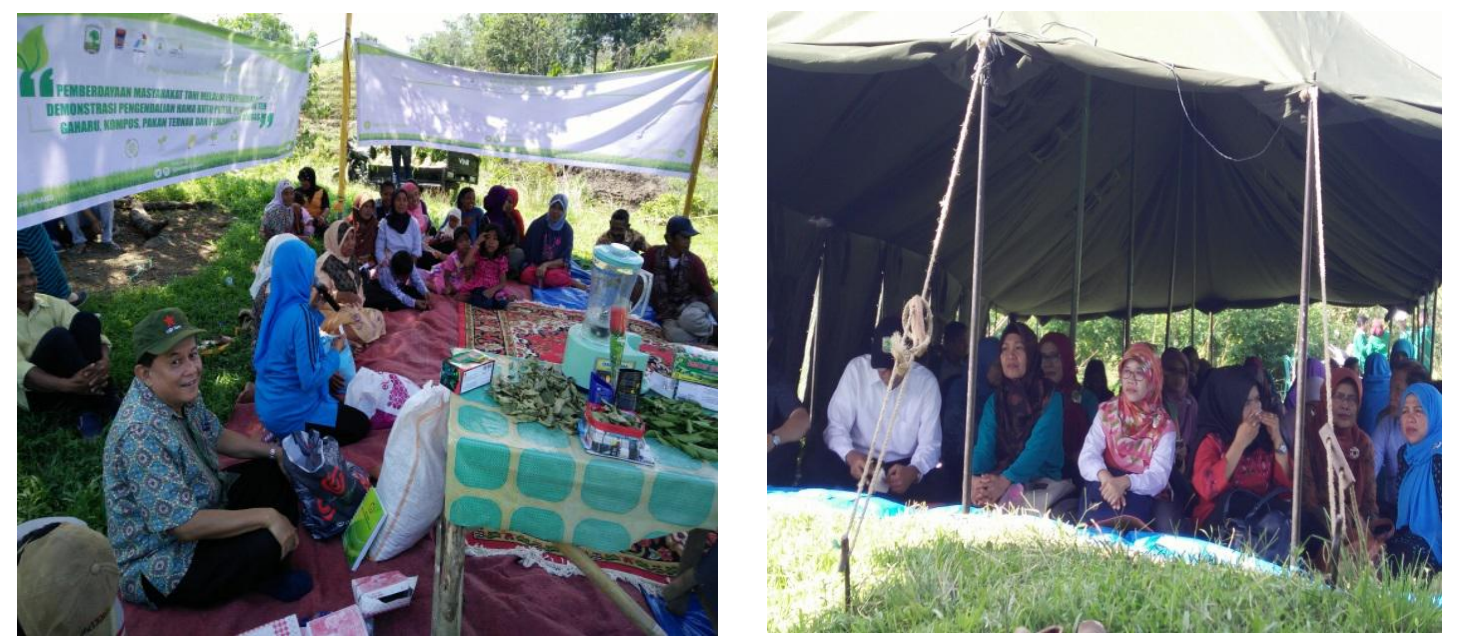

Gambar 1. Kondisi Anggota Kelompok Tani bersama Tim

Melalui penyuluhan ini masyarakat/anggota kelompok tani menjadi lebih memahami dan mengetahui manfaat daun dan gubal gaharu sebagai bahan baku teh 
untuk minuman kesehatan di samping sebagai obat. Dengan pemberian pengetahuan tentang daun tanaman gaharu sebagai bahan baku teh minuman kesehatan dan bahan baku obat ini yang dikaji berdasarkan hasil-hasil penelitian ataupun informasi yang diperoleh dari berbagai jurnal, tulisan di internet maka pengetahuan masyarakat menjadi meningkat sehingga kepercayaan akan manfaat daun tanaman gaharu juga meningkat sehingga tidak ada lagi keragu-raguan lagi untuk menggunakan teh dan obat dari tanaman gaharu ini.

Pada kegiatan penyuluhan budidaya tanaman gaharu dan pemanfaatannya dilakukan pembagian bibit gaharu sekitar 150 batang dan bibit durian 500 batang kepada anggota kelompok tani peserta sekaligus penanaman bibit gaharu secara simbolis, dan ternyata semua anggota kelompok tani yang hadir menerima dengan sangat baik, bahkan ada diantaranya yang ingin memesan bibit tambahan untuk ditanam di kebunnya. Dari hasil pemantauan terhadap bibit yang telah dibagikan ternyata seluruh bibit telah tertanam di lahan anggota kelompok tani, dan melalui penggunaan Mikoriza multi spora pada dosis $20 \mathrm{~g}$ per lubang tanam, bibit gaharu dan durian tubuh dan berkembang dengan baik, mencapai $100 \%$.

Pelatihan yang diberikan adalah dalam bentuk demonstrasi proses pembuatan teh gaharu sebagai minuman kesehatan dari daun dan gubal tanaman gaharu, mulai dari memilih pohon yang akan diambil daun, tunas dan gubal gaharu dan penanaman bibit (Gambar 2), penjemuran, sampai proses pencincangan daun dan gubal gaharu dan packaging dan pembuatan desain kotak (Gambar 3).
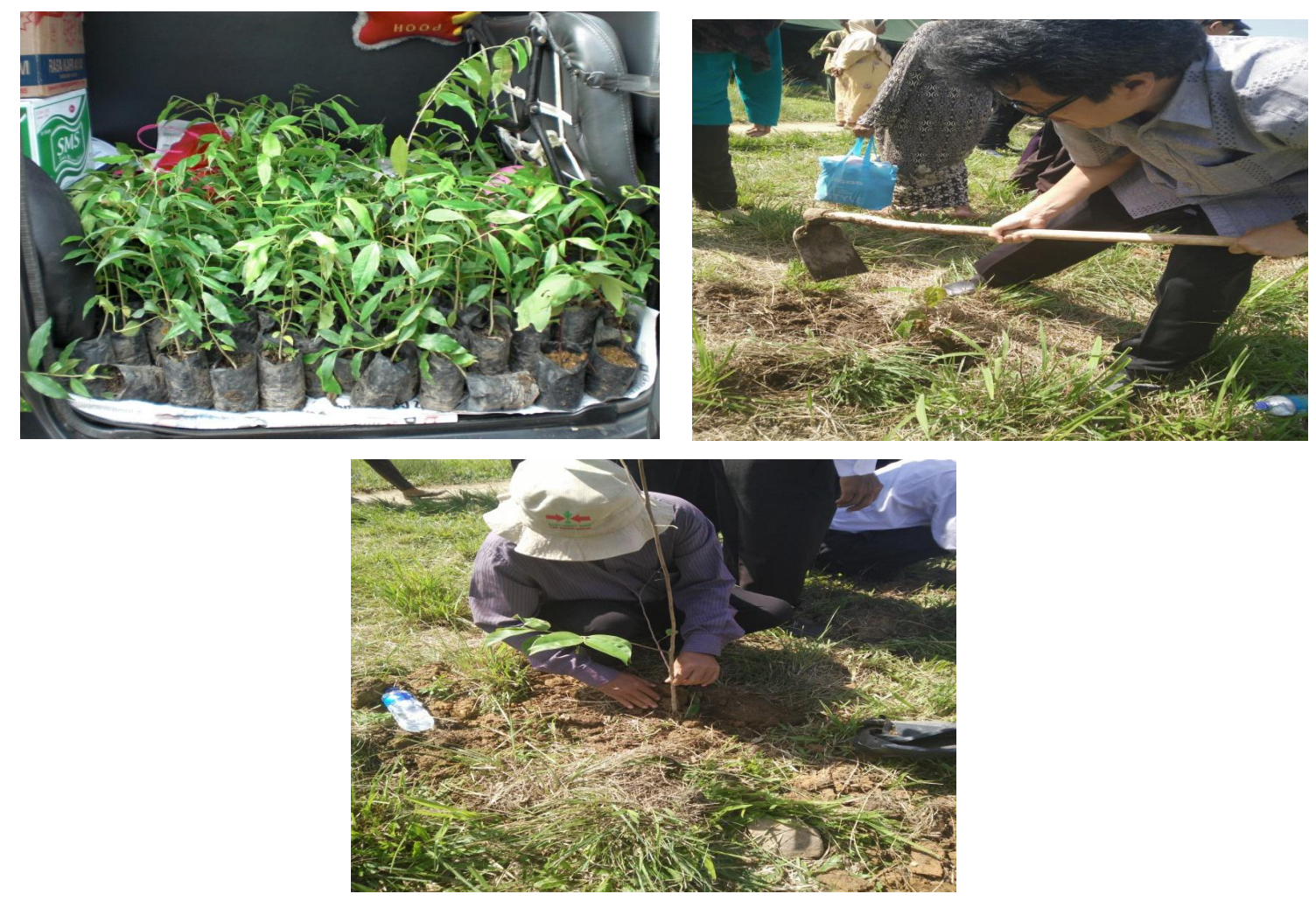

Gambar 2. Bibit Gaharu dan Penanaman Secara Simbolis

Teknologi Pengolahan Teh Herbal Dari Tanaman Gaharu di Kelurahan Lambung Bukik Kota Padang Benni Satria dkk. Hal. 211-219 

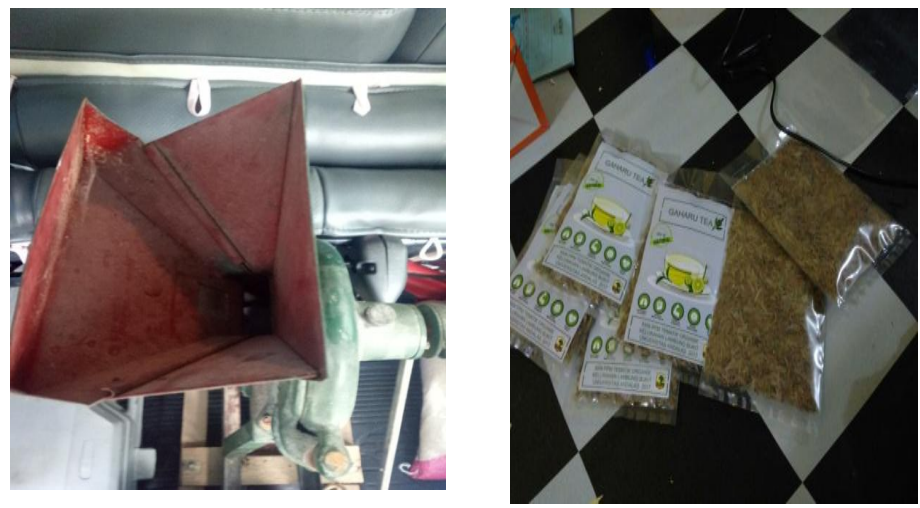

Gambar 3. Alat Pengolahan dan Packaging Teh Gaharu

Mengolah daun dan gubal tanaman gaharu menjadi produk minuman dan obat kesehatan ini maka akan dapat menjadi peluang usaha yang produktif bagi masyarakat. Masyarakat diharapkan dapat membentuk kelompok usaha yang bergerak di bidang minuman herbal dan obat-obatan ini dengan memanfaatkan bahan baku dari daun dan gubal gaharu yang ada di lingkungan sendiri.

Munculnya usaha yang produktif ini, berpeluang menghidupkan kembali sektor perekonomian masyarakat, sehingga masyarakat kembali bergairah untuk menata perekonomiannya dan segera bangkit dari keterpurukkan ini.

\section{KESIMPULAN DAN SARAN}

Kelompok tani Sungkai Permai telah memperoleh pengetahuan tentang budidaya tanaman gaharu serta pemanfaatannya dan telah menanam lebih kurang 500 bibit durian dan 150 batang bibit gaharu dalam pola tanam agroforestri dengan pohon kakao dan kopi, yang berguna sebagai bahan baku teh. Pertumbuhan bibit gaharu mencapai $100 \%$ dan Durian 100\% dengan menggunakan Mikoriza multi spora pada dosis 20 g per lubang tanam. Kelompok tani ini telah memperoleh pengetahuan dan teh mampu membuat teh gaharu sebagai minuman dan obat kesehatan dari daun dan gubal gaharu. Bahan baku daun dan gubal gaharu yang berasal dari pohon gaharu sekitar lahan petani di kelurahan Pauh atau daerah lain dapat dikelola oleh Keltan Sungkai Permai dapat menjadi peluang usaha produktif sebagai teh dan obat dalam bentuk minuman kesehatan untuk meningkatkan perekonomian masyarakat

\section{UCAPAN TERIMA KASIH}

Ucapan terima kasih penulis sampaikan kepada Bapak Rektor melalui LPPM telah memberikan dana DIPA Program Studi, Bapak Walikota Padang, Rektor Unand, Ketua LPPM Unand beserta Staf, Dekan Faperta, IKA Unand dan Dinas Pertanian kota 
Padang, beserta stafnya, Dosen Unand, PMI Unand, Mapala Unand, Gubernur BEM dan mahasiswa Faperta, yang telah berpatisipasi dalam kegiatan dana DIPA Program Studi. Begitu pula dengan kelompok tani Sungkai Permai dan masyarakat di sekitarnya yang telah berpartisipasi sehingga kegiatan ini dapat berjalan sebagaimana mestinya.

\section{DAFTAR PUSTAKA}

Brilliant, A. B, I. Indah, S, M. Larasati dan S. Eka. P. 2020. Iptek berbasis inkubasi inovasi dan dunia usaha: market research produk produk inovasi universitas andalas. Jurnal Hilirisasi IPTEKS, 3 (2): 133.

Ihsan. Z., S. Efendi, D. Rezki, I. Mirza. dan D. Suhendra. 2020. Pemberdayaan Masyarakat Nagari Silago Kabupaten Dharmasraya melalui teknologi budidaya tanaman kelapa sawit. Jurnal Hilirisasi IPTEKS. 3(1) Maret 2020.

Khaeruni. A, Rahayu, G. Ayu. K, dan T. C. Rakian P. 2020. Pemberdayaan masyarakat Desa Aunupe dalam pengolahan hama dan penyakit tanaman yang ramah lingkungan. Jurnal Hilirisasi IPTEKS. 3 (1), Maret 2020.

Raesi, S, B. Satria, Irawati dan Warnita. 2008. Sosialisasi dan Demonstrasi Budidaya Tanaman Penghasil Gaharu di Kenagarian Pamuatan Kecamatan Kupitan Sijunjung. Laporan Pengabdian Masyarakat, Dana Ipteks Dikti. 31 hal.

Satria, B, Gustian, E. Swasti, dan Kasim. 2008. Karakteristik morfologi dan genetik tanaman penghasil gaharu endemik Sumatera Barat. Jurnal, XI (1), Akreditasi No.55/Dikti/Kep/2005

Satria, B, Gustian; E. Swasti, dan Kasim. 2008. Identifikasi Spesies Tanaman Gaharu Di Beberapa Kabupaten di Sumatera Barat. Mapeni Indarung Padang, Padang. Disertasi

Satria, B. 2009. Manfaat Tanaman Gaharu Ditinjau Dari Kesehatan. Padang Ekpress. Hal 9.

Satria, B., R. Putih, D. Hervani, dan E. Swasti. 2009. Demonstrasi Budidaya Tanaman Penghasil Gaharu di Kelurahan Lubuk Minturun Kota Padang. Laporan Pengabdian Dana Dipa Unand. 32 hal.

Satria, B., Fauza. H, Darmawan Yaherwand, Zainal, A, Frizia F, Evaliza D, Ferita. I, M. Zen. Y, Mayerni. R, Noer. M dan Halbazar. T. 2012. Pemanfaatan Teknologi Tepat Guna Untuk Peningkatan Pertumbuhan dan Hasil tanaman karet dan Kakao di Kabupaten Dharmasraya. Laporan Pengabdian Dana DIPA Program Studi Agroteknologi Kampus III Dharmasraya. 14 Hal 
Satria, B., Fauza, Hayati, Swasti, Gustian dan Jamsari. 2012. Pemanfaatan Daun Tanaman Gaharu Sebagai Bahan Teh Untuk Kesehatan di kelurahan Limau Manih. Laporan Pengabdian Dana DIPA Program Studi Agroteknologi Faperta Unand. 24 Hal.

Satria, B., Raesi. S, Aspul. F dan Hendri. 2014. Sosialisasi Budidaya Tanaman Gaharu, Pengolahan Gaharu Dan Demplot Tanaman Gaharu Serta Pembagian Bibit. Artikel Ilmiah pengabdian masyarakat dana Lustrum Faperta Unand. ke-12. 9 Hal.

Syaiful. F. L., E. Purwati, Khasrad, Suyitman, dan Evitayani. 2019. Pemberdayaan masyarakat melalui deteksi kebunting dini sapi potong pada kelompok ternak di Kota Padang. Jurnal Hilirisasi IPTEKS, 2 (4a): 379-387.

Syaiful F. L dan F. Agustin. 2019. Diseminasi teknologi pakan komplit berbasis bahan baku lokal pada sapi potong di daerah Kinali, Pasaman BARAT. Jurnal Hilirisasi IPTEKS. 2(1): 79-87

Yanti, Y., H. Hamid, Reflin dan N. Hemeria. 2020. Pemberdayaan kelompok tani Sawah Payo Kabupaten Tanah Datar melalui teknik pemangkasan tanaman kakao. Jurnal Hilirisasi Ipteks, 3(2): 91-93. 